\title{
Analysis of factors associated with mortality in major burn patients
}

\author{
Cem Emir Güldoğan ${ }^{1}$, Murat Kendirci ${ }^{2}$, Emre Gündoğdu ${ }^{1}$, Ahmet Çınar Yastı ${ }^{3}$ \\ ${ }^{1}$ Clinic of General Surgery, Ankara Liv Hospital, Ankara, Turkey \\ ${ }^{2}$ Clinic of General Surgery, Hitit University Training and Research Hospital, Çorum, Turkey \\ ${ }^{3}$ Clinic of General Surgery, Ankara Numune Training and Research Hospital, Ankara, Turkey
}

* This study was presented at the $8^{\text {th }}$ Congress of the International Society for Burn Injuries, 28 July-1 August 2016, Miami, USA.

\begin{abstract}
Objective: Major burn injury is a type of trauma with high morbidity and mortality rates at all age groups. There is no consensus on the provided guidelines regarding the prediction of severity of the victims. Not being accessible to sophisticated clinical and blood monitoring in developing countries, it remains a challenge for them. The aim of the present study was to analyze the factors that have an effect on mortality and serve as a guide for burn treatment. Factors affecting mortality in major burn patients treated in a burn treatment center of a third step hospital with over $30 \%$ of burns of the total body surface area were evaluated, and parameters indicating severity were specifically determined.

Material and Methods: Medical records and follow-up notes of patients hospitalized in Ankara Numune Education and Research Hospital Burn Center between 2008 and 2014 were evaluated retrospectively. Data on age, gender, comorbidities, burn percentage, locality, type of burn, process of the burn (suicide or accident), presence of inhalation injury, results of blood hemogram and biochemical tests, length of hospitalization, type of surgical procedures performed, presence of multitrauma, and ventilatory support requirement were analyzed to determine the factors affecting mortality. White blood cell count, hemoglobin count, platelet count, and lactate dehydrogenase level were examined at admission, at the middle of the clinical course, and at the end of treatment (at both exitus date or discharge date).

Results: A total of 224 patients were hospitalized with burns $\geq 30 \%$ total body surface area. Of the 224 patients, $81.7 \%$ were males, and $18.4 \%$ were females. In the mortality group, $41.3 \%$ were males, and $58.5 \%$ were females. Gender (female, $p<0.041)$, age $(p<0.001)$, age group $(0-14 / 15-59 />60$ years, $p<$ $0.001)$, total body surface area $(p<0.001)$, type of burn (flame, $p<0.002)$, presence of inhalation injury $(p<0.001)$, process of the burn ( $<<0.002)$, time spent between the event and admission to the hospital $(p<0.001)$, length of hospitalization $(p<0.001)$, presence of comorbidity $(p<0.038)$, diabetes mellitus $(p<$ $0.05)$, ventilation support $(p<0.001$ ), lactate dehydrogenase values (lactate dehydrogenaseadmission, $p<0.001$; lactate dehydrogenasemiddle, $p<0.015$; lactate dehydrogenaselast, $p<0.001)$, white blood cell count $(p<0.001)$, and platelet count $(p<0.043)$ were found to be significant for univariate analyses. These parameters were further evaluated using multivariate analyses. Lactate dehydrogenaselast level $(p<0.001)$, age $(p<0.001)$, length of hospitalization (negative odds ratio), $p<0.001)$, presence of inhalation injury ( $<<0.029)$, total body surface area burned $(p<0.029)$, and leukocytosis $(p<0.006)$ were found to be significantly associated with mortality; however, leukocytosis and length of hospitalization did not pose risk for mortality with regard to odds ratios.

Conclusion: Early recognition of the factors affecting morbidity and mortality in patients and taking preventive measures, in addition to earlier detection and prevention of complications in long-time intensive care unit patients, could reduce complication and mortality rates in major burn trauma patients. Parameters for the indication of severity and mortality are important; however, lactate dehydrogenase is an easily studied parameter and is found to have a predictive value on prognosis.
\end{abstract}

Keywords: Burn, major burn, burn and mortality

Cite this article as: Güldoğan CE, Kendirci M, Gündoğdu $E$, Yastı AÇ. Analysis of factors associated with mortality in major burn patients. Turk J Surg 2019; 35 (3): 155-164.

\section{Corresponding Author}

Cem Emir Güldoğan

E-mail: drguldogan@gmail.com

Received: 18.12 .2017

Accepted: 21.02 .2018

Available Online Date: 20.11.2018

( C) Copyright 2019 by Turkish Surgical Society Available online at www.turkjsurg.com

DOI: $10.5578 /$ turkjsurg.4065

\section{INTRODUCTION}

Major burn injury is a type of trauma with high morbidity and mortality rates at all age groups. There is no consensus on the standard guidelines regarding the prediction of the severity of the victims. At times, it is not easy to have sophisticated clinical and blood monitoring in developing countries and is still a challenge for them. Although the incidence of burn injuries has decreased significantly over the recent years, approximately 1.1 million individuals receive treatment for burn injuries each year in the United States. Approximately 45.000 of these cases are hospitalized. There are 4500 deaths due to burn injury every year (1). In the USA, burns are the fourth leading cause of death due to accidents (2). Deaths occur more frequently among young children and elderly individuals (3). Burn injuries mostly occur due to lack of attention and lack of education, and burns result in physical and psychological scars. 
Burn is a life-threatening injury. It is a unique type of trauma that requires rehabilitation during and after treatment. As it is preventable, it presents an extra burden on the medical staff, the patients and their relatives, the hospital, and the national economy. For that matter, prevention and development of measures should be considered in the first place. One important factor associated with mortality and morbidity in patients with major burns is fluid resuscitation. Proper and convenient fluid resuscitation has been shown to extend life span especially in major burns.

The present study evaluated the factors associated with mortality in patients with burns, whose affected total body surface area (TBSA) was 30\% or higher, and who were hospitalized for treatment in Ankara Numune Education and Research Hospital Burn Treatment Center between 2008 and 2014. Our aim was to analyze injuries caused by major burns, determine mortality rates, and provide guidance in the treatment of major burns by identifying the risk factors associated with mortality.

\section{MATERIAL and METHODS}

The study was designed according to the Declaration of Helsinki, patient rights regulation, and ethical rules. The study was approved by the ethics committee of Ankara Numune Education and Research Hospital. We retrospectively reviewed clinical records and follow-up notes of patients hospitalized for treatment in the Burn Treatment Center of Ankara Numune Education and Research Hospital Hospital between 2008 and 2014.

In order to identify the prognostic risk factors associated with mortality, age, sex, comorbidity, affected TBSA, burn type, whether it was an accidental or suicidal case, presence of inhalation injury, results of hemogram and biochemical tests, length of hospitalization, presence of multitrauma, presence of ventilatory support, and cause of mortality were evaluated.

The study only included patients whose affected TBSA was 30\% or higher. White blood cell (WBC) count, hemoglobin level, platelet count, and serum lactate dehydrogenase (LDH) level were examined in particular. Additionally, LDH levels were examined at admission, at the middle of the clinical course, and at the end of treatment (at both exitus date or discharge date).

Statistical analyses were performed with 95\% confidence interval. A p-value < 0.05 was accepted as statistically significant. Comparisons were performed by using t-tests, and categorical data were compared using Chi-square or Fisher's exact test as appropriate. Factors associated with mortality were assessed by using Hosmer-Lemeshow test for logistic regression analysis.

\section{RESULTS}

\section{Demographic Data}

We retrospectively evaluated the demographic data of 224 patients who were hospitalized for treatment in our hospital's burn unit between January 2008 and January 2014 and whose affected TBSA was $\geq 30 \%$.
Of these 224 patients, 183 (81.7\%) were males, and 41 (18.4\%) were females. Median patient age was 37 years (min: 1 and max: 95). Patients were classified into three age groups: 13 (5.8\%) patients in the $0-14$ years age group, 184 (82.1\%) patients in the 15-59 years age group, and 27 (12.1\%) patients in the 60 years or older age group. Based on the type of burns, 153 (68.3\%) patients were exposed to flames, 42 (18.8\%) patients were exposed to electrical current, 18 (8.8\%) patients were exposed to hot fluids, and 11 (4.9\%) patients were exposed to chemicals or had contact burns.

Patients were evaluated according to the presence of comorbidities, and 40 (21.7\%) patients had a comorbid disease. Diabetes mellitus, hypertension, and chronic obstructive pulmonary disease (COPD) were the frequently observed comorbid diseases. Burn surfaces were as follows: 53.7\% (TBSA burned) for all patients, 53.6\% for males, and 54\% for females.

Length of hospitalization was accepted as the duration from patient's admission until problem-free discharge or death. All patients were followed up in the burn intensive care unit (ICU). Mean length of ICU stay was $26.42 \pm 25.27$ days. Patients were categorized based on respiratory support requirement. Non-invasive and/or invasive respiratory support was applied in 124 (55.3\%) patients. Overall, 99 patients died during the hospitalization period.

In order to determine the effects of prognostic risk on mortality, age, sex, comorbidities, affected TBSA, presence of inhalation injury, length of hospitalization, time until presentation, whether it was an accidental or suicidal case, burn type, presence of multitrauma, respiratory support, and cause of mortality were evaluated statistically.

There was a statistically significant difference between the two sexes regarding mortality rate $(p<0.041)$. Mortality rate was $58.5 \%$ in females, whereas it was $41 \%$ in males. There was a statistically significant relationship between mean patient age and mortality. Mean patient age in the surviving group was $31 \pm 14$ years, whereas mean age in the mortality group was $43 \pm 20$ years. There was a statistically significant difference between the different age groups regarding mortality rate $(p<0.001)$. The highest mortality rate was observed in the 60 years or older age group. No mortality was observed in the 0-14 years age group.

Mean affected TBSA was $53.7 \%$. Mortality rate among patients with TBSA greater than $30 \%$ was $44.2 \%$. There was a statistically significant relationship between TBSA and mortality $(p<0.001)$. There was a statistically significant difference regarding mortality rate between the different burn types $(p<0.002)$. Majority of our cases had burns after exposure to flames (68.3\%), and mortality rate was higher in the group exposed to flames (53.6\%), followed by electrical current, hot fluid, and others (chemical burns and contact burns). 
The presence of inhalation injury had a statistically significant effect on mortality $(p<0.001)$. Sixty-six $(67.3 \%)$ patients who developed inhalation injury lost their lives (Table 1). Time until presentation to the hospital had a statistically significant effect on mortality (Table 2).

Patients were categorized as accidental and suicidal cases based on the manner of injury. Mean TBSA was calculated in each group, and the distribution of affected TBSA was examined (Table 2). For cases that ended up with mortality, TBSA did not show any difference between these two groups. For surviving patients, affected TBSA was significantly larger among suicidal cases. This significant difference also caused TBSA to be different between the two groups in general. The relationship between the manner of injury and mortality was examined, and mortality rate showed a significant difference between accidental and suicidal cases, independent of the TBSA (Table 2). Length of hospitalization had a significant effect on mortality (Table 2).

In the present study, there were 40 patients with comorbidities. Of the 40 patients, nine had diabetes mellitus, nine had hypertension, three had concurrent hypertension and diabetes mellitus, four had COPD, three had mental retardation, three had epilepsy, five had coronary artery disease and heart failure, three had psychopathology, and one patient had volatile substance abuse. Patients were categorized in terms of the presence of comorbidity, and there was a statistically significant difference regarding mortality rate between patients with and without comorbidity (Table 2). Patients were categorized in terms of the presence of diabetes, and mortality rate was significantly higher among patients with diabetes (Table 2).
The presence of accompanying trauma did not have a significant effect on mortality $(p<0.815)$. In our case series, there were 20 patients with accompanying trauma. Mortality rate was $44.6 \%$ in the group with no accompanying trauma, whereas it was $40 \%$ in the group with accompanying trauma.

Respiratory support had a statistically significant effect on mortality rate (Table 2). Patients who had mortality were evaluated according to cause of death; accordingly, cause of mortality was multiple organ dysfunction syndrome (MODS) in 66 (66.7\%) patients, adult respiratory distress syndrome (ARDS) in 19 (19.2\%) patients, sepsis in 9 (9.1\%) patients, and other causes (pulmonary embolism, cranial embolism, and acute renal failure) in 5 (5\%) patients.

The relationship between laboratory parameters and mortality was analyzed. Accordingly, admission LDH levels, midhospitalization LDH levels, and end-hospitalization LDH levels and WBC and platelet counts were found to be associated with mortality. Alanine aminotransferase (ALT), aspartate aminotransferase (AST), and total bilirubin levels did not show a significant association with mortality (Table 3).

Logistic regression analysis was performed in order to determine the variables that will be used in the prediction of whether prognostic factors associated with mortality had any effect; further, sex, age, age group, TBSA, burn type, presence of inhalation injury, time until presentation, whether it was an accidental or suicidal case, length of hospitalization, presence of comorbid disease, presence of diabetes, LDH levels, WBC count, and platelet count yielded significant results as independent variables

Table 1. Relationships between demographical parameters and mortality

\begin{tabular}{|c|c|c|c|}
\hline & Survivors & Exitus & p \\
\hline Sex & & & 0.041 \\
\hline Female & $17(41.5 \%)$ & $24(58.5 \%)$ & \\
\hline Male & 108 (59\%) & 75 (41\%) & \\
\hline Age & 31.39 & 43.66 & 0.001 \\
\hline Age group & & & 0.001 \\
\hline $0-14$ years & $13(100 \%)$ & $0(0 \%)$ & \\
\hline $15-59$ years & 107 (58.2\%) & 77 (41.8\%) & \\
\hline$\geq 60$ years & $5(18.5 \%)$ & $22(81.5 \%)$ & \\
\hline TBSA & $47 \%$ & $63 \%$ & 0.001 \\
\hline Burn type & & & 0.02 \\
\hline Flame & 71 (46.4\%) & $82(53.6 \%)$ & \\
\hline Electrical current & 29 (69\%) & $13(31 \%)$ & \\
\hline Hot fluid & $16(88.9 \%)$ & $2(11.1 \%)$ & \\
\hline Others & $9(81.8 \%)$ & $2(18.2 \%)$ & \\
\hline Inhalation injury & 32 (32.7\%) & $66(67.3 \%)$ & 0.001 \\
\hline
\end{tabular}


Table 2. Associations between mortality and some parameters examined

\begin{tabular}{|c|c|c|c|}
\hline & Survivors & Exitus & $\mathrm{p}$ \\
\hline Time until presentation & & & 0.011 \\
\hline $0-24$ hours & $92(57.9 \%)$ & $67(42.1 \%)$ & \\
\hline 24-48 hours & $15(50 \%)$ & $15(50 \%)$ & \\
\hline$\geq 49$ hours & $18(51 \%)$ & $17(49 \%)$ & \\
\hline Manner of burn injury & & & 0.003 \\
\hline Accident & $118(58.3 \%)$ & $80(41.7 \%)$ & \\
\hline Suicide & $7(27 \%)$ & $19(73 \%)$ & \\
\hline Manner of burn and TBSA relationship & & & 0.002 \\
\hline Accident & 46.32 & 62.65 & \\
\hline Suicide & 51.86 & 62.74 & \\
\hline Comorbidity & & & 0.038 \\
\hline No & $113(61.4 \%)$ & $71(38.6 \%)$ & \\
\hline Yes & $12(30 \%)$ & $28(70 \%)$ & \\
\hline Diabetes & & & 0.005 \\
\hline No & $123(58 \%)$ & $89(42 \%)$ & \\
\hline Yes & $2(16.7 \%)$ & $10(83.3 \%)$ & \\
\hline Respiratory support & & & 0.001 \\
\hline No & 100 & 0 & \\
\hline Yes & $25(21.2 \%)$ & $99(79.8 \%)$ & \\
\hline Length of hospitalization (day) & 38.4 & 10.74 & 0.001 \\
\hline
\end{tabular}

Table 3. Distribution of laboratory parameters according to mortality state, and their effects on mortality

\begin{tabular}{|l|c|c|c|c|c|}
\hline & \multicolumn{2}{|c|}{ Survivors } & \multicolumn{2}{c|}{ Exitus } & P \\
\hline & Mean & SD & Mean & 495.09 & $\mathbf{0 . 0 0 1}$ \\
\hline LDH 1 & 468.59 & 470.14 & 664.4 & 816.34 & $\mathbf{0 . 0 1 5}$ \\
\hline LDH 2 & 323.92 & 149.27 & 605.57 & 1301.14 & $\mathbf{0 . 0 0 1}$ \\
\hline LDH 3 & 254 & 164.05 & 938.84 & 14861 & $\mathbf{0 . 0 0 1}$ \\
\hline WBC & 14260 & 9357 & 22362 & 173.662 & $\mathbf{0 . 0 4 3}$ \\
\hline Platelet & 279.885 & 145.806 & 235.247 & 498.38 & 0.121 \\
\hline ALT & 57.23 & 95.77 & 130.01 & 331.40 & 0.638 \\
\hline AST & 107.68 & 235.06 & 125.97 & 1.76 & 0.237 \\
\hline Total bilirubin & 1.02 & 2.37 & 1.42 & & \\
\hline SD: Standard deviation, LDH: Lactate dehydrogenase, WBC: White blood cell. & &
\end{tabular}

in chi-square significance analysis, and they were included in multivariable analysis. In order to determine the dependent variable prognostic factors associated with survival, forward stepwise selection technique was used for logistic regression analysis (Table 4).

Accordingly, based on the model formed with all independent parameters, end hospitalization LDH levels, age, length of hos- pitalization, inhalation injury, affected TBSA, and WBC count were parameters associated with mortality.

In the table, Exp ( $\beta p$ ) values indicate ORs. The OR represents the odds that an outcome will occur given a particular exposure, compared with the odds of the outcome occurring in the absence of that exposure. The probabilities will be interpreted in such a way that if $\beta$ coefficient is positive, the parameter will 
Table 4. Factors associated with mortality based on logistic regression analysis

\begin{tabular}{|c|c|c|c|c|c|c|c|c|}
\hline & \multirow[t]{2}{*}{ B } & \multirow[t]{2}{*}{ SE } & \multirow[t]{2}{*}{ Wald } & \multirow[t]{2}{*}{ df } & \multirow[t]{2}{*}{ Sig. } & \multirow[t]{2}{*}{$\operatorname{Exp}(B)$} & \multicolumn{2}{|c|}{$95 \% \mathrm{Cl}$ for EXP (B) } \\
\hline & & & & & & & Upper & Lower \\
\hline $\mathrm{LDH} 3$ & 0.005 & 0.002 & 10.891 & 1 & 0.001 & 1.005 & 1.002 & 1.008 \\
\hline Age & 0.08 & 0.021 & 15.154 & 1 & 0.001 & 1.083 & 1.041 & 1.128 \\
\hline Length of hospitalization & -0.096 & 0.021 & 21.248 & 1 & 0.001 & 0.909 & 0.873 & 0.947 \\
\hline Inhalation injury & 0.316 & 0.145 & 4.788 & 1 & 0.029 & 1.372 & 1.034 & 1.822 \\
\hline TBSA & 0.036 & 0.016 & 4.792 & 1 & 0.029 & 1.036 & 1.004 & 1.07 \\
\hline WBC & 0 & 0 & 7.604 & 1 & 0.006 & 1 & 1 & 1 \\
\hline
\end{tabular}

have an inverse relationship with mortality, and if it is negative, the parameter will be positively related with mortality.

According to the results, total length of hospitalization as a prognostic factor increased survival by 0.096 fold. On the other hand, mortality was increased by 0.005 fold with elevated end-hospitalization LDH levels, 0.08 fold with age, 0.316 fold with inhalation injury, and 0.036 fold with large affected TBSA.

As the classification success of our logistic regression model established to identify prognostic markers of mortality, the rate of accurate classification/accurate assignment of observations is 93.8\%. In other words, the model made accurate predictions in 93.8\% of the 224 patients. In this classification, six patients were misclassified in the surviving group, whereas five patients were misclassified in the mortality group. That is, $92.6 \%$ of patients who did not survive and $94.7 \%$ of the surviving patients were predicted with accuracy.

\section{DISCUSSION}

Our study included patients with 30\% or higher affected TBSA. Many factors have previously been associated with mortality in the literature. When we evaluate the association between sex and mortality, we observe that there is no consensus on this subject. Some authors have found female sex as a risk factor, whereas others have not found a significant association between sex and mortality $(4,5)$. In our study, $81.7 \%$ of patients were males, and $18.4 \%$ were females. In the group that ended up with mortality, $41.5 \%$ of patients were males, and $58.5 \%$ were females. There was a statistically significant association between sex and mortality in our study $(p=0.041)$. Accordingly, female sex can be interpreted as a risk factor. In their study, Kumar et al. (6) have examined causes of mortality among patients with major burns, and they have found mortality rate in female patients as $87.5 \%$. Liodaki et al. (7) have attributed higher mortality rate among females to greater adipose tissue volume, and they have stated that the adipose tissue functions as an active immune system organ responsible for increased systemic inflammatory response in burn trauma.
Although majority of the patients with major burns were young, an examination of the relationship between patient age and mortality showed that the mean age was 37 years (range: 0-95 years). Mean age of the patients in the mortality group was 43.66 years, and mean age in the surviving group was 31.39 years. Accordingly, there was a significant association between age and mortality $(p=0.001)$. Patients were evaluated according to age groups, and while there was no mortality in the 0-14 years age group, mortality rate was $41.8 \%$ in the $15-59$ years age group and $81.5 \%$ in the 60 years or older age group $(p=0.001)$. Ryan et al. (8) have found age older than 60 years as a risk factor for mortality. There are also other studies that report the association between advanced age and mortality $(9,10)$. Our results also indicate that advanced age is a significant risk factor for mortality.

In our study, the overall mean affected TBSA was 53.7\%. Affected TBSA was $62.7 \%$ in the mortality group and $46.63 \%$ in the surviving group. There was a statistically significant association between affected TBSA and mortality ( $p=0.001)$. There is a consensus in the literature that larger affected TBSA is associated with a high mortality rate (11-13). A recent study reported that affected TBSA over $40 \%$ is a risk factor for mortality. There are also other studies that found the mortality rate is $100 \%$ in the patient group with affected TBSA over 70\% (14-16). In our study, mortality rate among patients with affected TBSA 30\% or higher was $44.2 \%$.

According to burn types, burn injuries most frequently occurred due to exposure to flames (68.3\%); the second frequent cause was electrical current (18.8\%), followed by hot fluids and others (chemical burns and contact) (4.9\%). These results are consistent with previous studies from both developed and developing countries $(17,18)$. According to mortality rates in different types of burns, $53.6 \%$ of patients with flame burns, 31\% of patients with electrical burns, and $8 \%$ of patients with hot fluid burns were lost. There was a significant difference regarding mortality rates between different types of burns $(p=0.002)$. Previous studies have also found the relationship between mor- 
tality and type of burn (19). In comparison to previous studies in the literature, our case series included a higher proportion of patients with flame burn injuries. The reason for this may be that our clinic is a reference center in Turkey, receiving more complicated patients

According to the manner of burn injury, 198 (88.4\%) patients were injured as a result of accidents, whereas 26 (11.6\%) patients were injured due to suicide attempt. Of the patients, $41.7 \%$ of the accidental cases and $73 \%$ of the suicidal cases ended up with mortality. There was a significant difference regarding mortality rate between accidental and suicidal cases $(p=0.003)$. A review of the literature showed that mortality rate is higher among accidental cases of burn injury and is lower among suicidal cases. Mean affected TBSA in accidental cases that ended up with mortality was $62.65 \%$, whereas it was $62.74 \%$ in accidental cases with mortality, which indicates that affected TBSA on its own is not a cause of death in patients with flame burn injuries. Probably, physiopathological changes associated with flame burn injury are the reasons for increased mortality rate. We believe that further studies are necessary to clarify this relationship. The relationship between mean TBSA and mortality was statistically significant in both the accidental and suicidal groups ( $p=0.002)$.

According to the evaluation of the length of ICU stay and mortality, mean length of hospitalization was 10.74 days in the mortality group and 38.84 days in the surviving group. There are studies in the literature that show increased mortality rates with increased length of hospitalization (20). One shortcoming of the present study is that the study did not include patients with similar TBSA involved. Naturally, patients with higher TBSA involved may die in the early period due to burn shock, whereas causes of mortality at the long term are sepsis and multiple organ failure. Nonetheless, in order to draw a conclusion as prolonged length of hospitalization is a cause of mortality, one should conduct a prospective study including patients with similar TBSA involved. In our study, mortality rate was lower as the length of hospitalization increased, which can be explained by the fact that patients with larger affected TBSA were lost in the early period. Kala et al. (15) have reported that mean length of hospitalization is shorter when affected TBSA is above $50 \%$. When we examine patients with prolonged length of hospitalization, we observe that the majority were treated for burn injuries affecting the extremities, and that they developed complications related with these injuries (graft and flap requirement and amputation). These patients had longer length of hospitalization because the treatment of these complications and rehabilitation procedures in the convalescence period took a long time. There is a consensus in the literature regarding the relationship between length of ICU stay and mortality. Many studies have reported increased mortality rates with prolonged length of ICU stay (21-23).
In our study, the relationship between mortality and comorbidity was statistically significant $(p=0.038)$. Similarly, Thombs et al. (24) have reported that mortality rate is four times higher among patients with burn injury who had three or more accompanying diseases, independent of their age. The same study has examined the association of accompanying diseases with mortality and found that hypertension and diabetes are not associated with mortality. In our study, mortality rate was 70\% in the group with accompanying disease and 38.6\% in the group with no comorbidity. We examined the association of diabetes with mortality. Patients were categorized based on the presence of diabetes. The frequency of wound site infection, grafting and graft complications, length of hospitalization, and risk of nosocomial infection have been shown to be increased in the presence of diabetes (25). In our series, $83.3 \%$ of patients with diabetes ended up with mortality, whereas this rate was $42 \%$ in the non-diabetic group. Diabetes had a statistically significant positive effect on mortality rate $(p=0.005)$. There are also other studies in the literature that have found increased mortality rate in the presence of diabetes as a comorbidity.

Major burns may be accompanied by other types of traumas, including fall from heights, extremity fractures, spinal cord injuries, intracranial bleeding, and visceral organ injuries. Fractures most often occur at the upper extremities and vertebrae (26). Accompanying traumas are more likely to occur in case of electrical burns. In our study, a total of 20 (8.9\%) patients had an accompanying trauma, and 8 (40\%) patients ended up with mortality ( $p=0.815)$. Kaya et al. (27) have reported significantly increased mortality rates among patients with loss of consciousness. The same study has found a significant association between fall from heights and mortality.

Patients with burn injury are at risk due to several factors such as airway compression, requirement of endotracheal intubation, and mechanical ventilation. Inhalation of smoke causes damage to the upper respiratory tracts, and generalized massive edema in the body may cause obstruction of the respiratory tracts as well. Additionally, hypoxia that develops as a result of resuscitation during the initial treatment may lead to requirement for endotracheal intubation or mechanical ventilation. Furthermore, ARDS or acute lung injury in patients with burn may require ventilatory support (28). In our study, a total of 124 (55.4\%) patients received respiratory support. Among these patients, 99 (79.8\%) ended up with mortality. All patients who did not receive respiratory support survived. Mortality rate was significantly higher among patients who received respiratory support $(p=0.001)$. There is consensus in the literature that connection to mechanical ventilation and prolonged ventilation increase complications related to mechanical ventilation and, therefore, are associated with increased mortality (29-31). Nonetheless, it should be emphasized here that respiratory sup- 
port is an obligatory part of the treatment algorithm in patients with major burns. Before announcement of death, all patients are intubated and connected to the mechanical ventilator as a standard of care. Hence, it would be wrong if we interpret it in the way that mechanical ventilation increases mortality in such patients. In fact, patients requiring mechanical ventilation have organ failures already at a level that they cannot sustain their physiological respiratory functions, and their death has nothing to do with mechanical ventilation, but it is rather related to the progressing physiopathological processes that lead to mechanical ventilation requirement in the first place. As a result, we can interpret this result as that patients requiring mechanical ventilation had increased mortality rates. On the other hand, many studies have reported that prolonged mechanical ventilation increases mortality risk due to several factors associated with mechanical ventilators.

We evaluated complete blood count and blood chemistry parameters measured at the time of admission. Elevated WBC count $(p=0.001)$ and reduced platelet count $(p=0.043)$ were found to be statistically significant. Patients were classified according to ength of hospitalization. LDH levels measured at the time of admission, at the mid-term of the hospitalization period, and at the end of the hospitalization period were found to be associated with mortality ( $p<0.005)$. Total bilirubin, ALT, and AST levels measured at the time of admission did not show any association with mortality.

It is not fully understood why patients with burn injuries have elevated WBC count. It may be due to septic complications, thermal trauma, or inflammation (32). Orban et al. (33) have reported that $75 \%$ of the patients with major burn injuries have WBC counts above $12.000 / \mathrm{mL}$. Yanculovich et al. (9) have shown that WBC count at the time of admission, together with affected TBSA, is the most important prognostic factor for predicting mortality. We also observed elevated WBC count secondary to burn and trauma, consistent with that in the literature. However, this elevation does not stand out as an independent factor for mortality. In addition, the level of elevation was not found to be a significant parameter for death.

Platelets are cells free of nucleus in the circulation, and their principal function is to maintain hemostasis. They are additionally known to play roles in wound healing and cytokinemediated immune response. Platelets have been shown to be associated with sepsis and increased mortality in critically ill patients (34). Marck et al. (23) have reported that thrombocytopenia is associated with sepsis and is one of the predictive factors for mortality. Macedo et al. (35) have noted that thrombocytopenia and anemia are associated with mortality according to the results of univariate analysis, but the same association was not observed in multivariate analysis. Wolf et al. (15) have found that thrombocytopenia $(<20.000 / \mathrm{mL}$ ) is associated with mortality in patients with severe burns. We also found a statistically significant association between thrombocytopenia and mortality $(p=0.043)$.

Lactate dehydrogenase is an intracellular enzyme found in many tissues, particularly abundant in the kidneys, heart, skeletal muscle, brain, and liver. Its circulating levels rise in case of cellular injury. It is the most important enzyme of the last step of anaerobic respiration. There are five LDH isoenzymes, and these isoenzymes can be used to assess the origin of LDH elevation. Increased LDH 1 and LDH 2 isoenzyme levels can be observed following acute myocardial infarction, in hemolytic anemias, sickle cell anemia, megaloblastic anemia, acute renal cortical necrosis, and particularly skeletal muscle damage. Increased $\mathrm{LDH} 2,3$, and 4 isoenzyme levels can be seen in pulmonary embolism, following massive blood transfusions, in lymphomas, and skeletal muscle injury. Increased LDH 5 isoenzyme level occurs in liver diseases and cancers. Riaz Ahmed et al. (36) have reported that $\mathrm{LDH} 4$ and $\mathrm{LDH} 5$ isoenzyme levels can be used in patients with major burns with affected TBSA 30\% or higher as a diagnostic marker for the interpretation of the extent of injury and during follow-up of wound healing. Liu et al. (37) have studied LDH levels following burn injuries and found elevated $\mathrm{LDH} 4$ and LDH 5 isoenzyme levels, and they have stated that early detection of the elevated LDH levels may be beneficial in diagnosis and treatment. Karadaş et al. (38) have found an association between mortality and persistently elevated LDH levels. In our study, serum samples for LDH measurement were obtained at three different times. Patients were categorized based on their length of hospitalization. The first sample was obtained at the time of admission. Increased LDH level at the time of admission was found to be significantly associated with mortality for patients with major burns with 30\% or higher TBSA involved ( $p=0.001)$. Second serum LDH level was measured at the mid-term of the hospitalization period, and increased LDH level at this time was also found to be significantly associated with mortality $(p=0.015)$. The third sample was obtained at the end of hospitalization, and increased LDH level at this time was also significantly associated with mortality $(p=0.001)$. Based on the literature review, it could be concluded that analysis of LDH isoenzymes is necessary, whereas in this retrospective study, persistence of elevated LDH level or an increasing trend was directly related with mortality. At this point, it is deduced that increased LDH level is associated with mortality, without a requisition for isoenzyme analysis. In addition, isoenzyme studies were inadequate in revealing the origin of the elevation, and they failed to emphasize its clinical significance and also have a downside as the requirement of extra cost and time. Yet, based on our findings, we can say that LDH level can be used to predict mortality, without the need for isoenzyme analysis. 


\section{CONCLUSION}

Major burns are a type of trauma with high morbidity and mortality, and all age groups are at risk. The clinical picture in major burns involves various systems. Our study included a total of 224 patients with major burns who had 30\% or larger TBSA involved, and the overall mortality rate was $44.2 \%$.

We evaluated parameters that could be associated with mortality. Female sex, age, age group, affected TBSA, type of burn, presence of inhalation injury, time until presentation to our hospital, whether it was an accidental or suicidal case, length of ICU stay, presence of comorbid disease, presence of diabetes, and presence of accompanying trauma were found to increase mortality in patients with 30\% or larger TBSA involved in univariate analysis. Among the laboratory tests that were requested at the time of admission and during treatment, increased WBC count, elevated LDH level, and reduced platelet count were found to increase mortality. We observed that prolonged length of hospitalization had a favorable effect on survival in multivariate analysis.

In our study, the most frequent causes of mortality following burn injury were MODS, ARDS, sepsis, and others (pulmonary embolism, cranial embolism, and acute renal failure, among others). Although these clinical identities were mostly interrelated, they may also be encountered on an individual basis. Additionally, an extremely high WBC count at the time of presentation should be considered as a warning sign for possible serious inflammatory response or sepsis. Elevated LDH levels should prompt reconsideration of diagnostic and therapeutic protocols. Thrombocytopenia and disturbances of blood glucose regulation may be signs of sepsis development. It should be kept in mind that patients connected to the mechanical ventilator may develop secondary infections, and since these infections reduce survival, these patients should be disconnected from the mechanical ventilator.

Early recognition of factors leading to morbidity and mortality and taking necessary measures and, additionally, early detection of complications that may develop after long-term follow-up in the ICU, and proper actions would reduce both complication rates and mortality rates in patients with major burns.

From another perspective, the best way to reduce mortality associated with major burns is to prevent burn injuries.

Moderate and serious injuries should be treated in specialized centers for better outcomes. Owing to the advances in burn care, even patients with very large affected areas may survive with proper care. Future efforts should focus on the reduction of scar formation and the expedition of the healing process and will aim to improve functional and cosmetic outcomes.
Ethics Committee Approval: Ethics committee approval was received for this study from the Ethics Committee of Ankara Numune Education and Research Hospital.

Informed Consent: Not required in this study

Peer-review: Externally peer-reviewed.

Author Contributions: Concept - C.E.G., A.Y.; Design - C.E.G., M.K.; Supervision - A.Y.; Resource - C.E.G., E.G.; Materials - C.E.G., A.Y.; Data Collection and/or Processing - C.E.G., M.K., E.G.; Analysis and/or Interpretation - C.E.G., A.Y.; Literature Search - C.E.G.; Writing Manuscript - C.E.G., A.Y.; Critical Reviews - A.Y.

Conflict of Interest: The authors have no conflicts of interest to declare.

Financial Disclosure: The authors declared that this study has received no financial support.

\section{REFERENCES}

1. Imahara SD, Holmes IV JH, Heimbach DM, Engrav LE, Honari S, Klein $M B$, et al. SCORTEN overestimates mortality in the setting of a standardized treatment protocol. J Burn Care Res 2006; 27: 270-5. [CrossRef]

2. Atiyeh $B$, Masellis A, Conte C. Optimizing burn treatment in developing low-and middle-income countries with limited health care resources (part 1). Ann Burns Fire Disasters 2009; 22: 121-5.

3. Panjeshahin MR, Lari AR, Talei AR, Shamsnia J, Alaghehbandan $R$. Epidemiology and mortality of burns in the South West of Iran. Burns 2001;27:219-26. [CrossRef]

4. Sadeghi-Bazargani H, Mohammadi R, Svanstrom L, Ekman R, Arshi S, Hekmat $S$, et al. Epidemiology of minor and moderate burns in rural Ardabil, Iran. Burns 2010; 36: 933-7. [CrossRef]

5. Arshi S, Sadeghi-Bazargani H, Mohammadi R, Ekman R, Hudson D, Djafarzadeh $H$,et al. Prevention oriented epidemiologic study of accidental burns in rural areas of Ardabil, Iran. Burns 2006; 32: 366-71. [CrossRef]

6. Kumar S, Ali W, Verma AK, Pandey A, Rathore S. Epidemiology and mortality of burns in the Lucknow Region, India-a 5 year study. Burns 2013; 39: 1599-605. [CrossRef]

7. Liodaki E, Senyaman Ö, Stollwerck PL, Möllmeier D, Mauss KL, Mailänder $P$, et al. Obese patients in a burn care unit: a major challenge. Burns 2014; 40: 1738-42. [CrossRef]

8. Ryan CM, Schoenfeld DA, Thorpe WP, Sheridan RL, Cassem EH, Tompkins $R G$, et al. Estimates of the probability of death from burn injuries. N Engl J Med 1998; 1998: 1848-50. [CrossRef]

9. Noam Yanculovich MD, MA ZH. Objective estimates of the risk Factors for death and length of Hospitalization following Burn injuries, soroka university medical center, 2001-2002. Age 2013; 34: 40.

10. Tarim MA. Factors affecting mortality in burn patients admitted to intensive care unit. East J Med 2013; 18: 72.

11. Sozen 1, Güldoğan CE, Yasti AC. Etiology of childhood burns and parental awareness in Turkey. Ulus Cerrahi Derg 2016; 32: 168-72. [CrossRef]

12. Zarei MR, Dianat S, Eslami V, Harirchi I, Boddouhi N, Zandieh A, et al. Factors associated with mortality in adult hospitalized burn patients in Tehran. Ulus Travma Acil Cerrahi Derg 2011; 17: 61-5. [CrossRef]

13. WolfSE, Rose JK, Desai MH, Mileski JP, Barrow RE, Herndon DN. Mortality determinants in massive pediatric burns. An analysis of 103 children with $>$ or $=80 \%$ TBSA burns (> or $=70 \%$ full-thickness). Ann Surg 1997; 225: 554-65. [CrossRef] 
14. Stewart IJ, Cotant CL, Tilley MA, Huzar TF, Aden JK, Snow BD, et al. Association of rhabdomyolysis with renal outcomes and mortality in burn patients. J Burn Care Res 2013; 34:318-25. [CrossRef]

15. Kala Prakash Chandra. High Tension Electric Injuries in Western Rajasthan: A Review of 238 Patients New Indian Journal of Surgery. Jul 2011, Vol. 2 Issue 3, p141-152. 12p

16. Ercan GÇ, Özay H, Bombacı E, Çevik B, Çolakoğlu S. The Prognosis of Two Year Follow up of Burn Intensive Care Unit Patients. J Turk Soc Intens Care 2012; 10(3).

17. Qader AR. Burn mortality in Iraq. Burns 2012; 38: 772-5. [CrossRef]

18. Ibarra Estrada MÁ, Chávez Peña Q, García Guardado DI, López Pulgarín JA, Aguirre Avalos G, Corona Jiménez F. A 10-year experience with major burns from a non-burn intensive care unit. Burns 2014; 40: 1225-31. [CrossRef]

19. Stylianou N, Buchan I, Dunn KW. A model of British in-hospital mortality among burns patients. Burns 2014; 40: 1316-1321. [CrossRef]

20. Peck MD, Mantelle L, Ward CG. Comparison of length of hospital stay to mortality rate in a regional burn center. J Burn Care Rehabil 1996; 17: 39-44. [CrossRef]

21. Orban C, Tomescu D. The importance of early diagnosis of sepsis in severe burned patients: outcomes of 100 patients. Chirurgia (Bucur) 2013; 108: 385-8.

22. Kurtoğlu M, Alimoğlu O, Ertekin C, Güloğlu R, Taviloğlu K. Evaluation of severe burns managed in intensive care unit. Ulus Travma Acil Cerrahi Derg 2003; 9: 34-6.

23. Pavoni V, Gianesello L, Paparella L, Buoninsegni LT, Barboni E. Outcome predictors and quality of life of severe burn patients admitted to intensive care unit. Scand J Trauma Resusc Emerg Med 2010; 18:24. [CrossRef]

24. Thombs BD, Singh VA, Halonen J, Diallo A, Milner SM. The effects of preexisting medical comorbidities on mortality and length of hospital stay in acute burn injury: evidence from a national sample of 31,338 adult patients. Ann Surg 2007; 245: 629-34. [CrossRef]

25. Schwartz SB, Rothrock M, Barron-Vaya Y, Bendell C, Kamat A, Midgett $M$, et al. Impact of diabetes on burn injury: preliminary results from prospective study. J Burn Care Res 2011;32: 435-41. [CrossRef]

26. Koumbourlis AC. Electrical injuries. Crit Care Med 2002; 30(11 Suppl): S424-S430. [CrossRef]

27. Kaya H, Gökdemir Mt, Sögüt Ö, Sayhan MB. The Factors Affecting Mortality In Adults Due To High Voltage Electrical Injuries. Duzce Tip Fak Derg 2013; 15: 22-6.
28. Sözen I, Guldogan CE, Kismet K, Sabuncuoğlu MZ, Yasti AÇ. Outpatient burn management and unnecessary referrals. Ulus Travma Acil Cerrahi Derg 2015; 21:27-33. [CrossRef]

29. Mgahed M, El-Helbawy R, Omar A, El-Meselhy H, Abd El-Halim R. Early detection of pneumonia as a risk factor for mortality in burn patients in Menoufiya University Hospitals, Egypt. Ann Burns Fire Disasters 2013; 26: 126-35

30. Güldoğan CE, Kendirci M, Tikici D, Gündoğdu E, Yastı AÇ. Clinical infection in burn patients and its consequences. Ulus Travma Acil Cerrahi Derg 2017; 23: 466-71.

31. Meynaar IA, Knook AH, Coolen S, Le H, Bos MM, Van Der Dijs F, et al. Red cell distribution width as predictor for mortality in critically ill patients. Neth J Med 2013; 71: 488-93.

32. Lavrentieva A, Papadopoulou S, Kioumis J, Kaimakamis E, Bitzani M. $P C T$ as a diagnostic and prognostic tool in burn patients. Whether time course has a role in monitoring sepsis treatment. Burns 2012; 38 356-63. [CrossRef]

33. Fernandes FM, Torquato IM, Dantas MS, Pontes Júnior Fde A, Ferreira Jde A, Collet N. Burn injuries in children and adolescents: clinical and epidemiological characterization. Rev Gaucha Enferm 2012; 33: 13341. [CrossRef]

34. Ibarra Estrada MÁ, Chávez Peña Q, García Guardado DI, López Pulgarín JA, Aguirre Avalos G, Corona Jiménez F. A 10-year experience with major burns from a non-burn intensive care unit. Burns 2014; 40: 1225-31. [CrossRef]

35. Marck RE, Montagne HL, Tuinebreijer WE, Breederveld RS. Time course of thrombocytes in burn patients and its predictive value for outcome. Burns 2013; 39: 714-22. [CrossRef]

36. Ahmad R, Qayyum S, Hasnain AU, Ara A, Khan A, Alam M. Observation on the changes in lactate dehydrogenase isoenzymes in post-burn patients: significance in relation to creatine kinase. J Med Biochem 2009; 28: 16-21. [CrossRef]

37. LiU ZJ, Zhang Y, Zhang XB, Yang X. Observation and identification of lactate dehydrogenase anomaly in a postburn patient. Postgrad Med J 2004; 80: 481-3. [CrossRef]

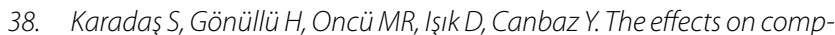
lications and myopathy of different voltages in electrical injuries. Ulus Travma Acil Cerrahi Derg 2011; 17: 349-53. [CrossRef] 


\title{
ORIJINAL ÇALIŞMA-ÖZET
}

Turk J Surg 2019; 35 (3): 155-164

\section{Majör yanıklı hastalarda mortalite ile ilişkili faktörlerin analizi}

\author{
Cem Emir Güldoğan ${ }^{1}$, Murat Kendirci ${ }^{2}$, Emre Gündoğdu ${ }^{1}$, Ahmet Çınar Yastı ${ }^{3}$ \\ ${ }^{1}$ Ankara Liv Hospital, Genel Cerrahi Kliniği, Ankara, Türkiye \\ ${ }^{2}$ Hitit Üniversitesi Eğitim ve Araştırma Hastanesi, Genel Cerrahi Kliniği, Çorum, Türkiye \\ ${ }^{3}$ Ankara Numune Eğitim ve Araştırma Hastanesi, Genel Cerrahi Kliniği, Ankara, Türkiye
}

\section{ÖZET}

Giriş ve Amaç: Majör yanıklar yüksek morbidite ve mortalite ile seyreden, tüm yaş gruplarının risk altında olduğu bir travma türüdür. Bu çalışmadaki amacımız yanıklara bağlı gelişen yaralanmaları analiz etmek, mortalite oranlarını belirlemek, mortaliteyi etkileyen risk faktörlerini belirlemek ve yanık tedavisinde yol göstermektir. Bu tez çalışmasında, üçüncü basamak bir sağlık kurumunun, yanık tedavi merkezinde, yanık yüzey alanı $\% 30$ ve üzeri olan majör yanıklı hastalarda, mortaliteye etki eden faktörlerin araştııılması amaçlanmıştır.

Gereç ve Yöntem: 2008-2014 yılları arasında Ankara Numune Eğitim ve Araştırma Hastanesi yanık kliniğine başvuran ve yatırılarak takip edilen hastaların klinik kayıtları ve takip notları geriye dönük olarak incelenmiştir. Hastalarda mortaliteye etki eden prognostik faktörleri tespit amacıyla yaş, cinsiyet, ek hastalık varlığı, yanık yüzdesi, hastanın geldiği yer, yanık türü, yanığın meydana gelişşsekli, inhalasyon yaralanması varlığı, kan hemogram testleri ve biyokimyasal değerleri, yatış süresi, operasyon tipi, multitravma varlığı, solunum desteği ve mortalite nedenleri incelecek parametreler olarak belirlenmiştir. Çalışmada hastaların başvuru anındaki beyaz küre düzeyi, hemoglobin düzeyi, trombosit düzeyi, laktat dehidrogenaz düzeyleri özellikle irdenlenmiştir. Bununla beraber hastaların hastanede yattığı süre zarfında, hastaneye başvuru anında bakılan laktat dehidrogenaz $(\mathrm{LDH})$ geliş değeri; yatış süresinin ortasında bakılan LDH orta değeri; ve yattığı sürenin sonunda bakılan LDH son değerleri de esas alınmıştır.

Bulgular: 2008-2014 yılları arasında, Ankara Numune Eğitim ve Araştırma Hastanesi yanık ünitesinde yatırılarak tedavi edilen hastalardan toplam vücut yanık alanı (TVYA) $\geq \% 30$ olan 224 hastanın demografik özellikleri, geriye dönük olarak incelendi. Çalışmamızda hastaların \%81,7'si erkek, $\% 18,4$ 'ü kadın olarak izlendi. Ölüm görülen grupta ise \%41,5 erkek, \%58,5 kadın mevcuttu. Univariyant analizde anlamlı çıkan veriler (cinsiyet, yaş, yaş grubu, yanık yüzey alanı, yanık türü, inhalasyon yaralanması varlığı, yanığın meydana gelişşekli, hastaneye başvuru süresi, yatış süresi, ek hastalık varlığı, diyabet, solunum desteği, LDH değerleri, lökosit değeri, trombosit değeri) multivaryant analiz ile değerlendirildiğinde; LDH çıkış değeri, yaş, yatış süresi, inahlasyon yaralanması varlığı, yanık yüzey alanı ve lökositoz istatistiksel olarak artmış mortalite riski ile ilişkili bulunmuştur.

Sonuç: Hastalarda morbidite ve mortaliteye etki eden faktörlerin erken dönemde fark edilmesi ve önlemlerin alınması ayrıca yoğun bakımda takip edilen hastaların uzun dönem takipleri sonrasında oluşabilecek komplikasyonların erken tanınıp tedbir alınması majör yanıklı hastalarda hem komplikasyon oranlarını hem de mortalite oranlarını azaltacaktır. Diğer bir bakış açısıyla majör yanıklara bağlı mortaliteyi azaltmanın en iyı yolu yanıklardan korunmaktır. Orta ve büyük şiddette yaralanmalar daha iyi sonuçlar alabilmek için bu konuda özelleşmiş merkezlerde tedavi edilmelidirler.

Anahtar Kelimeler: Yanık, majör yanık, yanık ve mortalite

Doi: $10.5578 /$ turkjsurg.4065 